Original Paper

\title{
Pelatihan Motivasi dan Orientasi Masa Depan Peserta Didik dengan Menggunakan Peta Mimpi
}

\author{
Yasmine Khairunnisa $^{1 *}$, Fitria Rizkiana ${ }^{1}$, Herlina Apriani ${ }^{1}$, Emilda Prasiska $^{1}$ \\ ${ }^{1}$ Program Studi Pendidikan Kimia, Universitas Islam Kalimantan Muhammad Arsyad Al-Banjari, Banjarmasin, \\ Indonesia.
}

*Corresponding Author:

Yasmine Khairunnisa, Program

Studi Pendidikan Kimia,

Universitas Islam Kalimantan

Muhammad Arsyad Al-Banjari,

Banjarmasin, Indonesia;

Email: ichbinjasmine@gmail.com

\begin{abstract}
Abstrak: Sebagian besar anak-anak di SMAN 1 Kandangan tidak memiliki rencana masa depan yang jelas sesuai dengan keinginan mereka; masa depan mereka ditentukan oleh orang tua ataupun keadaan. Maka dari itu, kegiatan pengabdian kepada masyarakat dilaksanakan dengan tujuan untuk memupuk motivasi siswa-siswi di sekolah melalui pelatihan atau workshop untuk membantu mereka menemukan semangat belajarnya demi meraih cita-cita yang diinginkannya, serta membantu peserta didik yang masih kebingungan untuk memutuskan rencana masa depannya agar mampu secara mandiri merencanakan kehidupannya. Kegiatan ini dilaksanakan dalam bentuk workshop atau pelatihan dengan konsep seminar menggunakan media peta mimpi yang berisikan bagan rencana dari tahun 2018 hingga 2028. Pada kertas tersebut, peserta didik menuliskan secara rinci rencana masa depannya dalam rentang waktu 10 tahun. Kegiatan pengabdian kepada masyarakat di SMAN 1 Kandangan ini berjalan dengan lancar dan mendapat antusiasme yang besar dari siswa. Namun, kurang panjangnya waktu yang disediakan menyebabkan siswa kesulitan untuk mengisi peta mimpinya karena siswa terkesan dituntut untuk tiba-tiba menuliskan rencana masa depan secara detail tanpa diberikan waktu untuk berpikir. Dari hasil angket siswa didapatkan bahwa sebagian besar siswa memiliki minat yang besar untuk belajar dan meneruskan pendidikannya, serta mereka memiliki motivasi yang mendasari semangat mereka untuk belajar yang dipengaruhi oleh orang tua, teman, dan lingkungan sekitarnya.
\end{abstract}

Kata kunci: motivasi; masa depan; peta mimpi

\section{Pendahuluan}

Pendidikan merupakan tonggak kehidupan suatu bangsa dimana kunci dari kemajuan bangsa adalah meningkatnya kualitas sumber daya manusia yang ditandai dengan kualitas pendidikannya (MarizaFitri \& Derlina, 2015). Kualitas pendidikan dapat dilihat dari berbagai aspek, salah satunya adalah produk dari pendidikan itu sendiri. Produk yang dimaksud disini adalah luaran atau lulusanlulusan yang dicetak oleh lembaga kependidikan, yaitu peserta didik; Seperti yang dinyatakan oleh Raharjo (2012) bahwa salah satu komponen penting untuk mewujudkan pendidikan yang optimal adalah kompetensi lulusan. Berdasarkan Kementerian Pendidikan dan Kebudayaan (2012), Indonesia adalah Negara yang mencanangkan wajib belajar dua belas tahun dari sekolah dasar hingga sekolah menengah atas; namun, kenyataan yang terjadi di masyarakat justru berbanding terbalik. Jumlah lulusan yang dicetak oleh sekolah menengah pertama masih sedikit jika dibandingkan dengan jumlah siswa yang masuk sekolah dasar (Ulfatin, Mukhadis, \& Imron, 2010). Banyak anak yang putus sekolah dikarenakan biaya maupun kurangnya pemahaman akan pentingnya pendidikan (Suyanto, 2010).

Sebagian besar anak-anak tidak memiliki rencana masa depan yang jelas sesuai dengan keinginan mereka; masa depan mereka ditentukan oleh orang tua ataupun keadaan. Akibatnya, motivasi siswa dalam menuntut ilmu dan mencapai 
cita-citanya menjadi terkalahkan oleh keadaan yang menuntut mereka untuk menjalani takdirnya tanpa berusaha mewujudkan mimpinya. Berkaitan dengan hal tersebut, dampak dari rendahnya motivasi siswa adalah kurangnya lulusan-lulusan dari sekolah menengah yang kemudian berdampak pada minimnya peserta didik di tingkat perguruan tinggi dan akhirnya peluang kerja bagi mereka kecil. Sedangkan, kemajuan suatu Negara salah satunya dilihat dari jumlah dan peluang kerja bagi rakyatnya (Ali, 2009).

Dari hal kecil berupa motivasi anak berdampak pada hal yang besar yaitu kualitas pendidikan Negara. Efek domino ini akan terus terjadi jika tidak ada upaya untuk mengatasi akar permasalahan yang ada, yaitu motivasi dan perencanaan masa depan yang matang. Pengabdian kepada masyarakat ini dilaksanakan di SMA Negeri 1 Kandangan, masih banyak siswa yang tidak terlalu berminat untuk melanjutkan pendidikannya dikarenakan motivasinya yang rendah. Pengabdian ini difokuskan kepada motivasi siswa karena penulis beranggapan bahwa motivasi adalah hal yang krusial; mengatasi akar permasalahan dari dalam diri siswa harus dilakukan terlebih dahulu sebelum memperbaiki strategi pembelajaran dan pengajaran ataupun mengembangkan media dan model pembelajaran.

\section{Metode Pelaksanaan}

Kegiatan ini dilaksanakan dalam bentuk workshop atau pelatihan dengan konsep seminar menggunakan media peta mimpi. Peta mimpi adalah media berukuran kertas A3 yang berisikan bagan rencana dari tahun 2018 hingga 2028. Pada kertas tersebut, peserta didik menuliskan secara rinci rencana masa depannya dalam rentang waktu 10 tahun. Langkah-langkah yang dilaksanakan saat kegiatan berlangsung adalah: (1) Perkenalan kegiatan dan anggota tim, (2) Penjelasan mengenai kegiatan yang sedang dilaksanakan, (3) Pelatihan atau penyampaian materi workshop dalam bentuk seminar tentang motivasi dan orientasi masa depan, (4) Sesi pertanyaan bagi peserta untuk memastikan peserta memahami mengenai kosep motivasi dan orientasi masa depan yang disampaikan, (5) Pembagian peta mimpi oleh tim pelaksana, (6) Peserta diminta untuk mengisi peta mimpi sekreatif mungkin selama \pm 30 menit, (7) Selama pengerjaan, tim pelaksana membimbing peserta didik yang perlu bantuan, (8) Presentasi hasil peta mimpi di depan kelas oleh peserta didik yang bersedia, (9) Pemberian kenang-kenangan bagi peserta didik yang mempresentasikan hasil pengerjaan peta mimpinya, (10) Penyampaian kesimpulan dari materi kegiatan yang diberikan selama pelatihan dan foto bersama.

Hasil dari kegiatan ini juga didapatkan dari hasil angket yang diisi oleh siswa setelah kegiatan berlangsung untuk mengetahui motivasi, minat, dan perencanaan siswa terhadap pendidikannya di masa depan. Angket tersebut berisi 30 pertanyaan dengan pilihan jawaban "Sangat setuju (skor $=4$ )", "Setuju (skor $=3$ ), "Kurang setuju (skor $=2$ )", dan "Sangat tidak setuju (skor =1)". Sasaran dalam kegiatan ini adalah peserta didik yang berada di tingkat sekolah menengah atas di Hulu Sungai Selatan. Setelah dilakukan survey, sasaran kegiatan dikhususkan pada siswa-siswi kelas XI SMAN 1 Kandangan yang berlokasi di desa Hamalau.

\section{Hasil dan Pembahasan}

Dari hasil pelaksanaan kegiatan pengabdian kepada masyarakat yang dilaksanakan di SMAN 1 Kandangan, dapat dilihat bahwa antusiasme siswa dalam mengikuti materi sangat baik. Terlebih saat siswa diminta untuk mengisi peta mimpi dengan berimajinasi secara bebas tanpa dibatasi apapun, siswa sangat bersemangat untuk membuatnya sebaik mungkin. Namun, waktu yang disediakan cukup sempit sehingga siswa terkesan terburu-buru dalam mengerjakannya. Siswa mampu merencanakan masa depannya secara berurutan walaupun belum terlalu mendetail. Hal ini kemungkinan disebabkan oleh waktu yang singkat untuk pengerjaan peta mimpi itu sendiri. Selain itu, beberapa siswa masih ada yang belum selesai mengerjakan peta mimpi saat waktu habis, dan bahkan ada yang belum mengerjakan sama sekali. Bagi siswa yang tidak sempat menyelesaikan peta mimpinya, hal itu disebabkan karena mereka dituntut untuk memikirkan rencana masa depan yang sebelumnya belum terpikirkan oleh mereka, sehingga banyak dari mereka yang memberikan tanggapan bahwa mereka perlu waktu untuk memikirkannya. Akibatnya, sebagian besar waktu 
digunakan untuk merencanakannya terlebih dahulu, kemudian dituangkan ke dalam peta mimpi. Dari hal ini dapat dilihat bahwa sebagian besar siswa belum mampu merencanakan masa depannya dengan rinci dan terurut. Di sisi lain, ada beberapa siswa yang tidak mengerjakan sama sekali, bahkan tidak menunjukkan ketertarika untuk mengerjakannya. Hal ini kemungkinan disebabkan oleh tidak adanya minat mereka untuk merencanakan masa depannya. Hal ini juga dibuktikan dengan hasil angket motivasi siswa yang disajikan pada Tabel 1.

Tabel 1. Hasil Data Angket Motivasi Siswa (\%)

\begin{tabular}{|c|c|c|c|c|}
\hline Siswa & $\begin{array}{l}\text { Tidak } \\
\text { Setuju }\end{array}$ & $\begin{array}{l}\text { Kurang } \\
\text { Setuju }\end{array}$ & Setuju & $\begin{array}{l}\text { Sangat } \\
\text { Setuju }\end{array}$ \\
\hline 1 & 0.0 & 0.0 & 16.1 & 83.9 \\
\hline 2 & 25.8 & 67.7 & 6.5 & 0.0 \\
\hline 3 & 0.0 & 0.0 & 22.6 & 77.4 \\
\hline 4 & 0.0 & 3.2 & 29.0 & 67.7 \\
\hline 5 & 0.0 & 12.9 & 54.8 & 32.3 \\
\hline 6 & 0.0 & 9.7 & 41.9 & 48.4 \\
\hline 7 & 0.0 & 3.2 & 48.4 & 48.4 \\
\hline 8 & 38.7 & 61.3 & 0.0 & 0.0 \\
\hline 9 & 0.0 & 3.2 & 41.9 & 54.8 \\
\hline 10 & 0.0 & 3.2 & 19.4 & 77.4 \\
\hline 11 & 0.0 & 0.0 & 32.3 & 67.7 \\
\hline 12 & 0.0 & 22.6 & 74.2 & 3.2 \\
\hline 13 & 0.0 & 3.2 & 58.1 & 38.7 \\
\hline 14 & 0.0 & 6.5 & 48.4 & 45.2 \\
\hline 15 & 22.6 & 67.7 & 9.7 & 0.0 \\
\hline 16 & 6.5 & 35.5 & 58.1 & 0.0 \\
\hline 17 & 12.9 & 80.6 & 6.5 & 0.0 \\
\hline 18 & 19.4 & 80.6 & 0.0 & 0.0 \\
\hline 19 & 0.0 & 0.0 & 22.6 & 77.4 \\
\hline 20 & 0.0 & 0.0 & 58.1 & 41.9 \\
\hline 21 & 22.6 & 77.4 & 0.0 & 0.0 \\
\hline 22 & 0.0 & 22.6 & 67.7 & 9.7 \\
\hline 23 & 0.0 & 19.4 & 67.7 & 12.9 \\
\hline 24 & 6.5 & 77.4 & 16.1 & 0.0 \\
\hline 25 & 0.0 & 6.5 & 61.3 & 32.3 \\
\hline 26 & 0.0 & 3.2 & 41.9 & 54.8 \\
\hline 27 & 0.0 & 19.4 & 74.2 & 6.5 \\
\hline 28 & 22.6 & 74.2 & 3.2 & 0.0 \\
\hline 29 & 0.0 & 9.7 & 83.9 & 6.5 \\
\hline 30 & 0.0 & 32.3 & 61.3 & 6.5 \\
\hline
\end{tabular}

Dari Tabel 1, pada pertanyaan nomor 1, yaitu mengenai adanya keinginan siswa untuk melanjutkan kuliah sebanyak $16.1 \%$ siswa menjawab setuju dan $83.9 \%$ menjawab sangat setuju. Hal ini menunjukkan bahwa semua siswa berkeinginan untuk melanjutkan kuliah. Namun, sebaliknya pada nomor 2 yang berisi pertanyaan mengenai apakah siswa tidak berminat untuk melanjutkan pendidikan karena banyaknya pengangguran yang ada, sebanyak $6.5 \%$ setuju akan pernyataan tersebut. Walaupun angka ini terbilang kecil, namun dapat dilihat bahwa masih ada siswa yang tidak berminat untuk melanjutkan pendidikan. Kemungkinan besar siswa yang termasuk dalam persentase ini merupakan beberapa siswa yang tidak berminat untuk mengisi peta mimpi seperti yang dijelaskan sebelumnya. Hal ini disebabkan oleh persepsi siswa yang menyatakan bahwa untuk bisa bekerja, lebih dibutuhkan keterampilan bukan ijazah. Hal ini dibuktikan dari jawaban siswa pada pertanyaan nomor 15 dan 24 yang menunjukkan bahwa $9.7 \%$ siswa setuju bahwa ijazah itu tidak penting dan $16.1 \%$ siswa setuju bahwa jika memiliki keterampilan yang baik saja maka akan lebih mudah mendapat pekerjaan. Dalam kasus ini, sebagian besar siswa tidak beranggapan bahwa biaya merupakan halangan bagi mereka untuk melanjutkan pendidikan; hal ini terlihat dari respon siswa pada pertanyaan nomor 8 dan 21 dimana seluruh siswa menjawab tidak setuju dan sangat tidak setuju bahwa mereka tidak ingin melanjutkan pendidikan karena tidak ada biaya.

Berdasarkan hasil angket, semua siswa memiliki cita-cita yang menjadi alasan mereka untuk terus belajar dan sekolah; mereka beranggapan bahwa dengan berkuliah, mereka akan memiliki bekal keterampilan dan pengetahuan yang cukup agar bisa bersaing di dunia kerja. Namun, sebagian besar siswa, yaitu sebanyak $58.1 \%$ yang menjawab bahwa mereka juga ingin berkuliah karena faktor teman. Disini dapat kita lihat bahwa selain dari faktor dalam diri siswa, faktor lingkungan juga mempengaruhi keputusan siswa untuk melanjutkan pendidikan. Lingkungan dapat diartikan juga sebagai orang-orang yang ada di sekitar siswa; hal ini ditunjukkan pada pertanyaan nomor 10 dan 11, dimana semua siswa menyatakan bahwa mereka senang dan berminat untuk melanjutkan pendidikan dikarenakan adanya dukungan dari orang tua. Selain itu, pada pertanyaan nomor 12 , siswa juga memilih setuju bahwa motivasi mereka untuk melanjutkan pendidikan karena melihat para sarjana yang ada di sekitar mereka. Data ini menunjukkan bahwa faktor lingkungan, seperti teman, orang tua, dan orangorang sekitar memiliki pengaruh terhadap pola pikir anak dalam membuat pilihan untuk masa depannya, walaupun pilihan tersebut belum terencana secara 
detail. Terkait dengan motivasi dalam diri siswa, hal itu ditunjukkan siswa melalui rasa keingintahuannya yang tinggi mengenai informasiinformasi menyangkut perguruan tinggi, seperti yang mereka jawab pada nomor 22, 23, 29, dan 30; dimana siswa (bahkan siswa yang menyatakan tidak terlalu berminat untuk kuliah) mengumpulkan informasi mengenai perguruan tinggi melalui brosur, televisi, dan dari teman-temannya. Hal ini berarti bahwa siswa pada dasarnya memiliki keinginan dan kemauan yang cukup besar untuk melanjutkan pendidikan.

Dari keseluruhan kegiatan pengabdian kepada masyarakat, respon siswa cukup baik saat penyampaian materi, terlihat dari keaktifan siswa untuk bertanya dan menjawab pertanyaan. Selain itu, siswa juga terlihat tertarik terhadap materi yang disampaikan. Hanya saja, siswa masih perlu bimbingan lanjut dari guru dan orang tua untuk merencanakan masa depannya agar lebih terarah dan terencana, sehingga siswa mengetahui arah yang harus ia ambil dalam pendidikannya. Hal itu juga akan mendukung kesiapan dan kemapanan siswa untuk memulai merencanakan karirnya di masa depan.

\section{Kesimpulan}

Kegiatan pengabdian kepada masyarakat di SMAN 1 Kandangan ini berjalan dengan lancar dan mendapat antusiasme yang besar dari siswa. Namun, kurang panjangnya waktu yang disediakan menyebabkan siswa kesulitan untuk mengisi peta mimpinya karena siswa terkesan dituntut untuk tiba-tiba menuliskan rencana masa depan secara detail tanpa diberikan waktu untuk berpikir; tetapi dari hasil angket siswa didapatkan bahwa sebagian besar siswa memiliki minat yang besar untuk belajar dan meneruskan pendidikannya, serta mereka memiliki motivasi yang mendasari semangat mereka untuk belajar yang dipengaruhi oleh orang tua, teman, dan lingkungan sekitarnya. Selanjutnya, perlu diadakan peninjuan kembali melalui kegiatan serupa untuk melihat seberapa jauh peningkatan motivasi siswa dan seberapa matang persiapan mereka untuk melanjutkan pendidikan atau masa depannya.

\section{Saran}

Kegiatan yang berkaitan dengan motivasi siswa seperti yang ada dalam pengabdian kepada masyarakat ini sebaiknya dilakukan dalam beberapa kurun waktu agar terlihat ada atau tidaknya kemajuan siswa, serta perlu adanya alokasi waktu yang cukup panjang bagi siswa untuk mengisi peta mimpinya.

\section{Ucapan Terima Kasih}

Terima kasih kepada Universitas Islam Kalimantan Muhammad Arsyad Al-Banjari Banjarmasin yang telah mendukung secara moral dan material, serta berbagai pihak yang telah membantu jalannya kegiatan pengabdian kepada masyarakat ini.

\section{Daftar Pustaka}

Ali, M. (2009). Pendidikan untuk Pembangunan Nasional: Menuju Bangsa Indonesia yang Mandiri dan Berdaya Saing Tinggi. Jakarta: Grasindo.

KPD, K. (2012). Dokumen Kurikulum 2013. Jakarta: Kementerian Pendidikan dan Kebudayaan.

MarizaFitri dan Derlina. (2015). Pengaruh Model Pembelajaran Discovery Learning Terhadap Hasil Belajar Siswa pada Materi Pokok Suhu dan Kalor. Jurnal Inpafi, 3(2), 89-96.

Raharjo, S. B. (2012). Evaluasi Trend Kualitas Pendidikan di Indonesia. Jurnal Penelitian dan Evaluasi Pendidikan, 16(2), 511-532.

Sudarnoto, L. F. (2016). Faktor-Faktor Determinan Pada Motivasi Kerja Guru Sekolah Dasar. Sekolah Dasar, 25(2), 91-99.

Suyanto, B. (2010). Masalah Sosial Anak. Jakarta: Kencana.

Ulfatin, N., Mukhadis, A., \& Imron, A. (2010). Profil Wajib Belajar 9 Tahun dan Alternatif Penuntasannya. Jurnal Ilmu Pendidikan, 17(1), 36-45. 